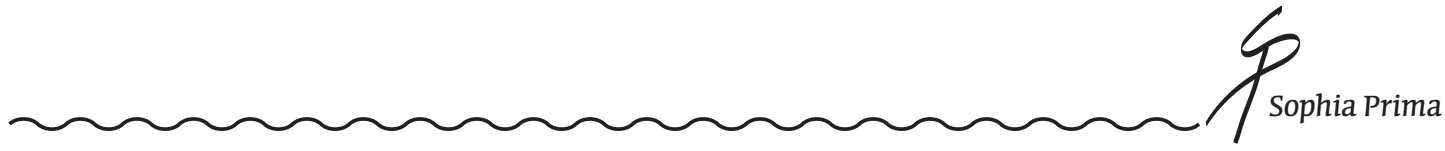

DOI:

UDC: 111.32:2-18-029: 3(092)

Maryna Zakharyna

$\mathrm{PhD}$ in Philosophical Sciences, Associate Professor, Chernigiv Polytechnic National University, Ukraine e-mail: zakharina_m@ukr.net ORCID: 0000-0002-7842-2460

\title{
WE READ TODAY: THE PHENOMENON OF THE INTEGRATED SOCIAL BEING IN V. ZENKOVSKY'S SOFIOLOGY
}

\author{
Working only for material goods, we are building \\ our own prison. And we lock ourselves alone, and all \\ our treasures are dust and ashes, they are powerless \\ to provide we have something to live for.
}

Antoine de Saint-Exupery

The publication proposes a set of theoretical and methodological approaches to the formation of a single philosophical and religious construction: "God - man - spirituality + freedom of will - active integrity of the individual - a holistic social system - a holistic philosophical and religious system", thus analyzing the emergence of a holistic personality, as the basis for the formation of a holistic social system, V. Zenkovsky's sophiology combines the process of functioning of two systemic projects - social and divine, it includes the realization of the relationship between God and a man on the basis of spirituality and freedom of will. It should be noted that from the point of view of the chronology of V. Zenkovsky's formation of the socio-economic project of arrangement of the social existence of European civilization, it is carried out in the period of economic decline and economic chaos of postwar Europe of the early twentieth century. Until recently, the implementation of such an approach was perceived as a social utopia, but to understand the need for such a way of unification, the global catastrophe of World War II had to take place.

Similarly, the Ukraine's desire to join the European family six years ago could be considered as the utopia, so we can state the praxeological aspect of the philosopher's prognostic ideas regarding the formation of a holistic social system. The unique project's possibilities of a single V.Zenkivsky's "economic orchestra" as a free cooperation of European nations on the harmonization principles of economic interests, personal origins and economic individualism are analyzed in the article. The attention is paid to the new holistic form foundation of economic life, which is close to the type of family sociality on the basis of initiative and creativity freedom. Conducting such an orchestra continues to be one of the main problems of the current complex of relations in the European Union, ranging from specific amounts of aid to less affluent EU member states to the Brexit situation in the United Kingdom. 
Keywords: man, society, sophiology, integral social existence, active integrity of personality, economic globalization.

Анотація. Захаріна М.І. Феномен цілісного соціального буття у софбіології В. Зеньковського. У публікації запропоновано комплекс теоретико-методологічних підходів до формування єдиної філософсько-релігійної конструкції: «Бог - людина - духовність + свобода волі - діяльна цілісність особистості - цілісна соціальна система - цілісна філософсько-релігійна система», тим самим було проаналізовано процес появи діяльнісної цілісної особистості як основи формування цілісної соціальної системи. Софіологія В. Зеньковського поєднує процес функціонування двох системних проєктів - соціального і божественного, він включає реалізацію відносин між Богом і людиною на засадах духовності та свободи волі. Необхідно відмітити, що з точки зору хронології формування В. Зеньковським соціально-економічного проєкту облаштування суспільного буття європейської цивілізації, то він здійснюється в період економічного занепаду та господарського хаосу післявоєнної Європи початку ХХ ст. До останнього часу реалізація такого підходу сприймалася як соціальна утопія, але для розуміння необхідності такого способу об'єднання мала відбутися глобальна катастрофа Другої світової війни. Так само утопією шість років тому можна було вважати прагнення України до вступу в сім'ю європейських народів, тому можемо констатувати праксеологічний аспект прогностичних ідей мислителя стосовно формування цілісної соціальної системи. У статті проаналізовано можливості унікального проєкту єдиного «економічного оркестру» В. Зеньковського як вільного співробітництва європейських народів на принципах гармонізації економіко-господарських інтересів, особистісному началі та економічному індивідуалізмі. Звертається увага на формуванні нової цілісної форми господарського життя, що є наближеною до типу сімейної соціальності на засадах свободи ініціативи та творчості. Диригування таким оркестром продовжує бути однією з головних проблем сучасного комплексу відносин у Європейському Союзі, починаючи від конкретних грошових сум допомоги для менш забезпечених країн-членів ЄС до ситуації брекзиту у Великій Британії.

Ключові слова: людина, суспільство, софіологія, цілісне соціальне буття, діяльна цілісність особистості, економічна глобалізація.

\section{Relevance of the research topic}

Modern society is rapidly transforming in all directions of its development and creates, on the one hand, conditions for a radically new progress of socio-economic change, and on the other hand, reduces the amount of time for spiritual self-deepening and self-improvement. It turned out that to understand the integrity of the new social system, it is necessary to significantly determine the life of each person. Today's challenges of the global world, which are particularly acute in the context of the COVID-19 pandemic, have led to the situation where the neglect of material and economic needs, indifference or provocative interference in their inner world, 


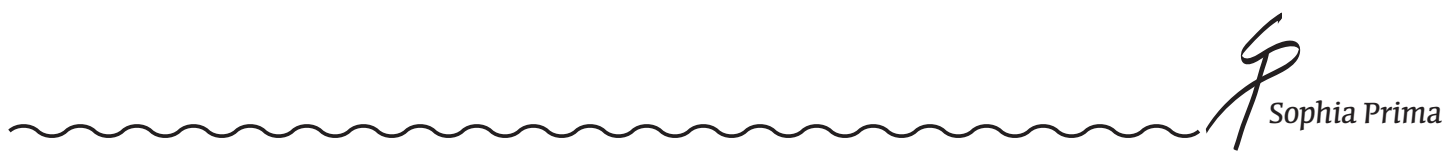

emotional and psychological intervention of information flows, reduces the ability to critically assess social-political situations, as well as the destruction of traditional worldviews, undermines faith in the possibility of personal protection and influence on the real course of events around their life.

V. Zenkovsky was an outstanding philosopher, theologian, psychologist, who turned to the analysis of the problems of the human personality in the period of social catastrophes and radical changes. He offered such methodological coordinates for the fundamental balancing in his intellectual searches: Jamming by the world, rejecting its true meaning and value (acosmism) and wrongly deifying the world, assimilating to the world those properties that clearly distort its created nature (naturalism) both of these "sins" of our time can be defeated only by revealing that doctrine of the world, which correctly explains its sophianity ${ }^{1}$, - if we use the well-known terminology of Kant - a regulatory one, rather than a constitutive idea, then the sophian understanding of the world remains ${ }^{2 \prime}$. We structurally design the sociological doctrine of the thinker in our research in such a constructive relationship as: "God - man - spirituality + freedom of will - active integrity of the individual - a holistic social system a holistic philosophical and religious system". We pay special attention to the original social project of the formation of a holistic social system of a single economic life of European countries proposed by the thinker. The basic principle of this project is the rational and prognostic positioning of the unique process of connecting the socio-economic coexistence of European countries on the basis of a single spiritual source and type of family sociality as a holistic system of internal unity.

\section{Analysis of recent research and publications}

The formation and development of the holistic social system idea is based on the approaches of such philosophers as A. J. Bahm, M. Buber, E. Husserl, G. Gunzl, A. Camus, N. Luhmann, E. Mounier, T. Parsons, P. Ricœur, J.-P. Sartre, P. Teilhard de Chardin, A. Schweizer, E. Fromm, C. G. Jung, K. Jaspers and many others. They identified the set of issues related to the personal responsibility, individual freedom and the social activity level, professional competence in the individual's life, environmental orientation and harmony of "relationships" with the outside world, etc. However, we find a kind of "primary" elaboration of these aspects in the works of M. Bakhtin, M. Berdyaev, V. Vernadsky, V. Solovyov, G. Skovoroda, P. Florensky, S. Franko, P. Yurkevich. The philosophical holistic responsibility concept can not be presented in several directions - a necessary condition for the study is the mandatory communication of interdisciplinary views on the human phenomena essence, which close intertwining opens the possibility of understanding this topic. For instance, since Socrates, the antiquity philosophers considered man a dual being, consisting of body and soul. Plato associated the soul with the idea, and Aristotle considered the soul as a form, etc. In medieval philosophy in the works of A. Augustine, V. the Great, G. Nizsky, and others the main difference between the man's body and soul is not so much as between

\footnotetext{
${ }^{1}$ Zenkovsky, Overcoming Platonism, 4.

${ }^{2}$ Zenkovsky, Overcoming Platonism, 24.
} 
"carnal" and "spiritual" man, and human nature is determined by three dimensions: physical, mental and spiritual.

\section{Setting the tasks}

Thus, the human's phenomenon analysis, its complex and contradictory nature, the intertwining of biological and socio-spiritual essence provides an opportunity to capture the ontological spirituality foundations in the general structure of human integrity and objective study of the procedure of its social self-realization, that is the ability of the sophiological doctrine of the world to transfer the universum of external existence into the inner world of a person is actualized.

\section{Research methodology}

Using the analysis methods, we aim to outline the content and practical application in the research theory of such methodological principles as polyphony or harmonious polyphony of ideas, dialogism as a way to create a semantic space of coexistence of thoughts, and biographical and hermeneutic method as a basis for human subjectivity analysis. They allowed to conduct the historical and philosophical concepts analysis, which are considered in the publication as complementary and such that complement each other in the research problem field. The importance is attached to the cooperative analysis methods to contrast the historical V.Zenkovsky's views with modern social theories and hermeneutics in order to explain and comment on the socio-economic philosopher's ideas through the prism of historical and cultural tradition. Important methods of the exploration are historical-comparative, functional-instrumental, axiological, system-structural, analytical-prognostic, which provide the relationship and connections analysis of the basic social dimension of modern reality.

\section{Presentation of the main materials of the study}

We can affirm that man is always a holistic person and their economic activity is not the exception, but we cannot single out any of its components, especially economic one, from the sphere of spiritual life. Each historical epoch has its homo economicus, and from Zenkovsky's point of view, the spiritual personality always occupies an important place in economic life. He draws attention to the fact that the modern economy is the organization of economic processes and the people's, nation's interests as a collective, living unity and pays great attention to the economic psychology study. On the such approach basis, the historical sense and the organization's logic of a national economy is formed. This indicates that there is always a factor of external state's influence on the economic life. That is why the internal transformation mechanism of social life should be formed on the transformation basis of inorganic relations between nations into organic ones, that is approximation of national and international life to the type of family sociality. A peculiar strategy of combining existing approaches is presented today in the modern economist's works: if the economy is based only on the selfish interests of a man (Homo economicus), which allegedly, according to the economic teachings of A. Smith, makes it possible to take into account public interests, then it, according to Russian philosopher M. Berdyaev, is dominated by bourgeois economy. If the interests of serving other people, society in general, come to the fore in economic life, then this corresponds to a socialist ideology that is closer to 
Christianity. If the economy of each country is built on the Christian economy principles, it will approach the divine. Perhaps that is why M. Gogol compared farming with a conversation with God, and G. Skovoroda spoke of the divine economy.

Strengthening the Christian economy foundations will help humanity to avert such phenomena, which are called by John the Theologian, signs of the end of the world ${ }^{3}$.

The two-thirds of the book were preserved in the creative V.Zenkovsky's heritage, which was devoted to economic issues and chronologically it belonged to the first years of his emigration. The philosopher defined his goal as an attempt to connect modern consciousness with Orthodoxy, as the view of it as something frozen and motionless was established. By the way, until the XIX century the doctrine of economics was related to the humanities, directly to ethics: "Philosophers-analysts thought something like this: "First, let's find out the status of the proposals of ethics. And as a result, let's define what values are. But the fact is that all the proposals of the humanities definitely deal with values" ${ }^{4},-$ therefore V. Zenkovsky considered his work only as "an introduction to the development of a holistic Orthodox system."

The second chapter of the book covers the assessment results of the Europe economic life after the end of the World War I, and the conclusions presented by V. Zenkovsky, we consider quite relevant in today's conditions. Analysis of modern socio-economic life makes it possible to understand that it is extremely complex. The emergence of machines, the advent of capitalism and the fall of subsistence farming led to the formation of a new economic system. Europe's economic development has risen sharply, and in only the nineteenth century has reached unprecedented proportions. Economic dynamics, of course, were not the same in all countries. The greatest economic success was demonstrated by Germany, England, the United States, and in other countries, due to various factors, the economy was much weaker, said the philosopher ${ }^{5}$. It is logical to turn to the views of the European classic on economic theory F. Braudel: "Outside the market an opaque area stretches, which is often difficult to observe due to the lack of sufficient historical data; it is that elementary basic activity that can be traced everywhere and the scale of which is simply fantastic. I called this vast area at ground level material life or material civilization, for lack of a better definition. The ambiguity of such an expression is obvious. But I believe that ... sooner or later there will be a better sign to define this infra-economy, this second, informal half of economic activity, this economy of self-sufficiency, the exchange of products and services in a very short radius. On the other hand, active hierarchical social structures rise above the huge surface of the markets, and not below it: they distort the process of exchange in their favor, shake the established order; wanting it, and sometimes not wanting it, they create anomalies, "vortices" and do their business in a very peculiar way" $^{\prime \prime}$, - such views on the economic life of peoples, when the uncertainty of their

\footnotetext{
${ }^{3}$ Mochernyi, Economic theory, 364-365.

${ }^{4}$ Kanke, V. A. Philosophy of Economic Science, 178.

${ }^{5}$ Zenkovsky, General laws of economic life, 72.

${ }^{6}$ Braudel, Civilization and Capitalism, 7.
} 
social relations and the constant crisis situations of material and objective existence are recognized, there is a turn to knowledge of these phenomena on the basis of substantial pluralism and recourse to change in all spheres of human life, not only in economics.

On the one hand, the economic processes of Europe take place, first of all, within the framework of nation-states, and on the other hand, on the contrary, the certain economic motives destroy the "borders" between individual states. This cannot be detached from spiritual transformations. European culture has common roots, and the spiritual development of Europe in the XIX century marked, at the very least, by a desire for the unity of an economically connected culture. We are witnessing a steady increase in economic interdependence, and the term "world market" is increasingly appearing at the level of politicians, academia and public opinion. Economic fluctuations in some countries have begun to affect the state of stability in neighboring countries, and sometimes lead to global economic crises. Accordingly, the concept of "world economic crises" gradually began to gain momentum, but its catastrophic and destructive nature was not initially recognized. Scientists have tried to summarize the facts about the crisis, to master the economic life sensitivity nature of individual countries towards crisis.

Today we can affirm that the Europenian economic development is based on the natural life spiritual source, but at the same time the consequences and motives go beyond national borders. The results of economic globalization have brought together significant political groups from different countries. Here we see the key motive of the dominant tendency: political imperialism is determined by powerful economic forces. The economic growth of Europe and its individual countries led to economic unity, which manifested itself, in particular, through the causes and consequences of the war of 1914-18. One of the key conclusions understood by the political elites was the understanding that no country can be completely independent, to be economically "closed" in itself. The realities of economic life imperatively require the unification of key groups and players, which ultimately leads to the unification of states into certain political alliances. Thus, in the economically developed countries, first of all Germany and England, deep imperialist aspirations were shown. Economic factors are becoming central to the system of major political processes. At the theoretical level, this position was enshrined in the system of "economic materialism", which tries to show the exceptional role of the economic factor in all significant historical processes ${ }^{7}$. Moreover, as noted by V. Zenkovsky, not all economic processes unfold in the interests of the ruling class, including the owners of the means of production. Key trends are formed completely independently of the particular class group interests. Economic integration can lead to global competition, which affects the weaker. The production differentiation and mechanization, the rapid economic relations complication, the growth of workers' consciousness - these factors create a great interdependence for all key players, and hence - between nation states. Some classes sometimes gain and sometimes lose. Economic transformations cannot be linked to

\footnotetext{
${ }^{7}$ Zenkovsky, General laws of economic life, 72.
} 
the interests of the proletariat or financial capital alone. But it is also correct to conclude that each new economic unification stage opens up certain opportunities for all classes, new "niches" for renewal. Under such circumstances, it can be argued that world history has never been so dependent on economic processes, economic laws have never been so visible and insurmountable. Economic integration has shown this trend very clearly. Machine production, even if we do not take the profound consequences, from the first days of its existence has made radical changes in public life - political, economic, social, military. Such production has given the economic systems of individual states unprecedented strength, and at the same time it has shown considerable weakness, primarily due to the growing interdependence of states. After World War I, it became clear that the economic catastrophe in Russia associated with its political system, represented by Bolshevism, made economic recovery impossible in Europe. Therefore, Europe objectively can not return to those forms of economic life that existed one hundred or two hundred years ago, so the search for a new world order began ${ }^{8}$, - but political consensus on economic issues is a very difficult task. These and other processes confirm the impossibility of going beyond the world economic system, and force a return to the pre-capitalist way of economic life. This method involved, in particular, the organization of economic life within nation-states. No matter what political storms rage over who will be the conductor in this economic orchestra, it is still impossible to pull at once, and by the powerful force of inevitable "fate" European nations, which do not know how to come to free cooperation, are still forced to achieve a certain unity. It becomes important to note that after the political defeat of Germany, the opposing forces, despite French resistance, can no longer evade the task of restoring Germany's economic power, because without this the economic recovery of the whole Europe is impossible. Under such conditions, the thesis of economic ineffectiveness of hostilities begins to be justified. It is impossible to reject any element, any country, regardless of its political preferences from the economic system of Europe, because the crisis in one country inevitably affects others. Just as no significant instrument can be removed from the orchestra without the possibility of achieving well-known sound results, so none of the more or less large state formations could be removed from the economic interaction of European countries without the greatest harm to others ${ }^{9}$. The unity of economic life in Europe, despite the economic systems of individual countries specifics, leads to cultural transformations, the very concept of European culture acts as a single organism (even with national characteristics). Due to the economic interdependence of European countries, all the negative processes taking place in one country pose a threat to other countries, even if they seem economically strong. The fate of Europe in its economic development has reached the point that, as a set of nation-states, it is united in political and economic terms, and thus in a cultural sense. Not formally united, although united in content, the European community conceals extraordinary contradictions (both external and internal). However, a united Europe lives its life despite its own desires, or the elites of

8 Zenkovsky, General laws of economic life, 73.

9 Zenkovsky, General laws of economic life, 73. 
individual countries' desires. European wars, whether Napoleonic or world ones, reveal the historical futility of mutual struggle, these wars ultimately lead to the Europe self-destruction, the all European civilization crisis, and testify to a deep historical and mental crisis.

Thus, according to V. Zenkovsky, it is necessary to get rid of the negative causes, the poison that persists in the depths of European culture, even if they can not change the movement of European history, but can bring it to the end. The world war of 191418 had catastrophic consequences for Europe, and it will not be possible to recover from these consequences quickly. If war was inevitable at the time of its beginning, but still it turned out to be a catastrophe in historical perspective. The war ruined a lot and eventually slowed down the historical process. Even the war of 1870 was convincing evidence that a solution to Europe's political problems could not be found through the use of military force. Subsequent events, including attempts to resolve the "Slavic question" around which the main political strata revolved and which remain unresolved due to Russia's temporary withdrawal from European states, testify to the urgency of the problem. In the economic environment, their "economic wars" have continued, continue and will continue in the future, but they are still unable to overcome certain differences in solving deep economic problems. It will be a disaster for Europe if it does not learn to find peaceful ways to solve the main problems of cooperation. It should be noted that such theses were proclaimed by V. Zenkovsky after the World War I.

In his works, the philosopher presented a detailed analysis of the main socio-economic system's features of contemporary Europe, when he defines economic and social individualism as the main characteristic of collective relations. We can say that this principle is inherent in all mankind, in part due to the influence spread of Roman private law. Turning to the works of W. Sombart on the capitalism development, the thinker makes a comprehensive analysis of those factors that directly influenced the economic life development at that time and which of them could be considered key factors of economic progress, the main of which he still considers the economic individualsm factor. Then V. Zenkovsky draws our attention to the socialist experiments of the Bolshevik government in the Soviet Union territory, rejecting even those ugly and senseless aspects of their activities that were inherent in them, with extreme brightness showed the impossibility of rejecting economic individualism from Europe. Meanwhile, socialism remains right in that it sees economic individualism as the main problem of modern Europe. On the other hand, with economic individualism, Europe is not only strengthening but also collapsing, this is its strength and weakness, that is, we face a situation of dual historical significance of economic individualism. The problem is that the main motive of economic activity was and remains the desire of the individual to accumulate wealth, and the basis of modern economic life is the principle of private property. He points out that "psychologists sometimes write that we have a property instinct. In my opinion, this view is correct, but I would like to dwell on one instinct aspect of this desire for property. We strive to make our property everything that is dear and necessary to us. This aspiration, however, is not 
the only thing that reigns in our souls. Along with this desire for power over property (over land, over objects, even over people), we develop a desire to adapt to others, to coordinate their own actions with their desires, with their aspirations. Both directions of this psychological movement are equally strong, equally insurmountable, and therefore in case of suppression or underdevelopment of any one of them, the person receives disturbance of mental balance. The desire to show individual will to power causes in us a powerful instinct for objects ownership ${ }^{10}$.

In addition, V. Zenkovsky provides a detailed various types of property differentiation, paying attention to their historical nature, and he claims that the laws of economic psychology are unchanged, and forms of economic life, in turn, changeable, so this approach can submit that the category of "property" has a socio-mental nature. If an evolutionary or revolutionary process of changing property take place, the legal system and mechanisms of legal regulation of relations that arise in new social conditions are changing: "The key to understanding the phenomenon of economic individualism lies in the property psychology. Economic individualism in its pure form is rare due to the fact that it is constantly complicated by various social phenomena, but this should not turn a blind eye to the fact that economic individualism is a phenomenon extremely characteristic of European culture"11.

A separate issue for the philosopher is the issue of economic values, he believed that they are endowed with a kind of impenetrability, which is similar to physical impenetrability. Just as the space filled by any body is impermeable to another body, so economic values occupy a certain place in the socio-economic space. The same object may not be the many subjects' property of economic relations, but the possession process of spiritual values has a completely different nature. Next, the philosopher reveals this specificity: in the socio-economic space, material value can be a thing of only one person, not several people, that is, such a value becomes "socially impenetrable" for others. And if several people seek to possess a particular subject, so their economic "interests" are aimed at this subject, then there inevitably appears an interest conflict and the struggle for such a value. Such a struggle may have the ordinary compromise character, but economic interest based on the laws of economic psychology, in itself raises the need to possess one or another material good. But it is ultimately determined by the demands and needs that I have now, which objectively available, but at the same time it is not able to influence the expansion or reduction of my requests. Conducting such an orchestra continues to be one of the main problems of the current complex of relations in the European Union, ranging from specific amounts of aid to less wealthy EU member countries to the Brexit process in the UK. But as the economic factor, such interests cannot change - all changes occur, so to say, from the "economic side". If a person has undergone a mental change, it will affect the economic interest, but the dynamics of economic interest as a phenomenon knows no compromises and allows only the exception of the opposite interest. Of course, economic activity cannot be detached from all socio-mental and individual mental activi-

\footnotetext{
${ }^{10}$ Zenkovsky, General laws of economic life.

${ }^{11}$ Zenkovsky, General laws of economic life, 76.
} 
ty. Therefore, the homo economicus concept, first introduced by Adam Smith, must be recognized as scientific fiction, because it distorts the concrete reality (although it can sometimes have great heuristic significance). The "struggle of interests" is inevitable as long as we proceed from "traditional" economic interests, but it should be borne in mind that such interests are objective, although formed by communities of people or individuals. Economic interests can be changed under the various internal or external reasons, just as people can change their demands ${ }^{12}$.

Thus, V. Zenkovsky claims that such a peculiar social "impenetrability" of material value and a constant struggle of interests has the character of not some kind of "evil" or predetermination, but acquires an objective phenomenon signs, which is due to the very nature of European development. The methodological approach in Zenkovsky's understanding of such economics philosophy problems is the idea that "the world is based on an ideal and holistic system. But this ideal and holistic system, which underlies the world, must at the same time be the living basis of it, must be the source of the creative forces guiding the entelechies, which tell the world relentless vitality... Nature in its sensual diversity natura naturata, but the same nature as natura naturans is its inexhaustible creative power, dominating time and space. The unity of natura naturans and natura naturata does not destroy their essential difference, but only certifies their fundamental, ontological homogeneity. Sophian foundation of the world cannot be separated and removed from the world of the senses, because it nourishes it, and directs it, informs it of its life and power ${ }^{13}$.

In the 19th and 20th centuries, according to the philosopher, an unprecedented struggle for economic existence unfolded, primarily due to the rapid growth of the population by revolutionary changes in the very economic life structure. The struggle for their economic interests has always been present in the material history of civilization, but at the same time, economic relations had a kind of stamp of the man who created it, and people at that time were acquainted with each other. This struggle could be fierce, and it was directed at certain people. Later, the gradual replacement of subsistence farming by exchange relations, and then by commodity-money relations, begins to alienate the producer of objects and their consumers until the economic process is no longer connected with personal relations. V. Zenkovsky points out in his work that "any product can be bought for money or their equivalents - this means that when extracting products, you have absolutely no communication with those who produced or delivered them. The material goods we need have resolutely become anonymous now, somehow separated. It is these considerations that justify what Marks aptly called "commodity fetishism": in our eyes, each product seems to have an "independent value", and only with the help of thought we can restore the socio-economic origin of this product, we can understand what creates its value" ${ }^{\text {"14 }}$,

\footnotetext{
${ }^{12}$ Zenkovsky, General laws of economic life, 83.

${ }^{13}$ Zenkovsky, Overcoming Platonism, 2-13.

${ }^{14}$ Zenkovsky, General laws of economic life, 85.
} 
- such a transformation of the psychology of economic life leads to the struggle for money as a universal value that provides the process of economic exchange.

V. Zenkovsky expresses a very important modern social life position that if there is anything personal left in modern economic life, it lies only in the struggle for money. The tragedy of this situation stems from the position that today we forget about the personal lives of the people behind these money, we can not see a living process of work, which "materializes" money, so accumulated in the sphere of economic life insults and misunderstandings between people are anonymous. This does not turn them into "pointless" feelings, but gives them a certain uncertainty. Often we need an object to which we can direct our resentment, our grievance. In this way, social myths quickly and easily create cash for anonymous resentment: social psychology shows that the basis of social communication is emotional rapprochement, and as emotional interaction transforms into a more specific form, it inevitably uses imagination. The impersonal, anonymous nature of economic relations in our time is particularly conducive to the emergence of myths. Nameless insults, resentment, hatred find their object with the help of imagination, and thus create and consolidate a certain social mythology, and it confuses and complicates the social process greatly. For example, each of us, immersed in social relations, seeks to achieve a particular social status, will inevitably feel that the condition of economic and social well-being is "money" - precisely because of their universal purchasing power. In the end, however, we do not need paper tokens of value (that is, money as an object), but certain goods that can be bought for money. With money, this universal regulator of economic life, we can feel independent, we can get exactly what we need. This universality of money in the process of social management becomes the main tool in achieving any economic or social goal. In addition, the anonymity associated with the existence of money obscures the real relationship behind money as the bearer of values - inevitably focusing a lot of attention on money. This situation leads to the fact that from a universal tool in economic life (primarily as a means of supporting the exchange of values) money becomes its universal goal, and this metamorphosis leads to the fact that the means to achieve the goal, coming to the fore, becomes a goal. In modern economic life, which has become anonymous, the consumer can not observe the living processes behind the production of goods, and also with the advent of the market those living processes in which their work was used were pushed away from the producer - this approach is exceptional. Dominant anonymity, which permeates all aspects of economic life, reinforces the so-called "monetary fetishism", and ultimately causes them to become a self-sufficient goal of economic activity ${ }^{15}$.

Thus, the universality of the purchasing power of money, due to the anonymity of modern relations, evokes the desire for money. A terrible mark of this general orientation towards money lies on our entire cultural life - the pursuit of money comes with greater force and exposure, the further the cultural process becomes more complicated, because of this there is some kind of devastation of the soul - the desire for money becomes, if not central, then still the dominant factor in activity, it puts its

\footnotetext{
${ }^{15}$ Zenkovsky, General laws of economic life, 85.
} 
stamp everywhere and on everything. From now on, noble aspirations are associated with the system of social relations and automatically become the "source" of income, receive a monetary rate ${ }^{16}$.

A very important position of the author, which has acquired a sharp modern significance in the spiritual life of Europe - is the search for understanding the economic psychology originality of modern people, this is what in the historical creative activity time of V. Zenkovsky was called "spiritual burgher" and not "consumer society". The thinker believes that "behind the world that is sensually accessible to us, changeable and transient, according to the Sophian concept, there is an ideal world, an eternal and true face of the world, free from disharmonies and contradictions, from coincidences of time and space. This ideal world invariably preserves the unity and integrity of the world, revealing itself in the inexhaustible creative forces power of nature "17. It is about the fact that people's desire to accumulate goods is closely intertwined with a mosaic of diverse spiritual processes and human life norms and can lead to spiritual energy loss: paying homage to the precepts of moral consciousness, we put between ourselves and people nothing but money. The main thing we want to help, what we see as the main cause of trouble, the main means to help are money. As a result, man, their uniqueness, inevitably goes to the background and our attitude to them becomes completely "soulless" and external. We absorb into ourselves what modern humanity lives and breathes; from an early age we are imbued with the realization that the path to values and their understanding lies through money, they open up all the possibilities of civilization to us. With the help of money, all countries, all achievements, all the best works of culture and art become available to us. Self-development, technology, science, even religious communication are easy and simple, if we are free to choose life paths, if we do not need to spend all our energy on "getting" money. Money becomes not only a universal means of purchase, they have become a condition and purpose (simultaneously!) of the overall cultural process ${ }^{18}$.

\section{Conclusions}

Thus, the teachings of V. Zenkovsky's sophiology combine the process of functioning of two systemic projects - social and divine, it includes the realization of the relationship between God and a man on the basis of spirituality and freedom of will. It should be noted that from the V.Zenkovsky's chronology point of view socio-economic project for the arrangement of the social life of European civilization is carried out during the period of economic decline and economic chaos in post-war Europe at the beginning of the 20th century. Until recently, the implementation of such an approach was perceived as a social utopia, but to understand the need for such a way of unification, the global catastrophe of World War II had to take place. Similarly, Ukraine's desire to join the European nations family six years ago could be considered the utopia, so we can state the praxeological aspect of the philosopher's prognostic ideas regard-

\footnotetext{
${ }^{16}$ Zenkovsky, General laws of economic life.

${ }^{17}$ Zenkovsky, Overcoming Platonism, 7.

${ }^{18}$ Zenkovsky, General laws of economic life, 90.
} 


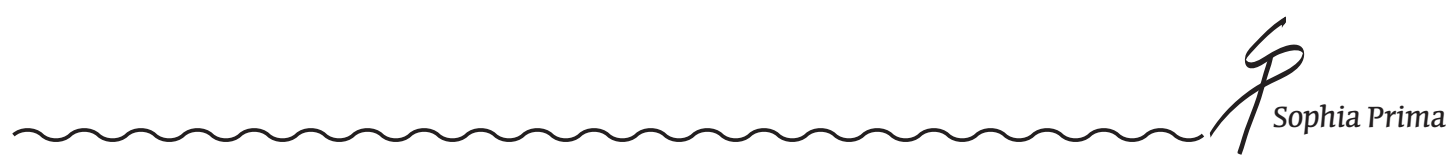

ing the formation of a holistic social system. Analyzing the unique project possibilities of a single "economic orchestra" V. Zenkovsky's attention is paid to the new holistic format of economic life, which is close to the type of family sociality on the freedom basis of initiative and creativity. Conducting such an orchestra continues to be one of the main problems of the modern complex of relations in the European Union, ranging from specific amounts of aid to less affluent EU member states to the Brexit situation in the United Kingdom.

\section{References}

Braudel, F. Civilization and Capitalism, 15th-18th Century. Vol. 1. The Structure of Everyday Life. Translated by G. Filipchuk. Kyiv: Osnovy, 1995.

Zenkovsky, V. V. "General laws of economic life." Bulletin of the Russian Christian movement. Paris - New York - Moscow, 1991, no. 161: 71-101.

Zenkovsky, V. Overcoming Platonism and the Problem of the Sophian Creature. Accessed June 23, 2020. https://azbyka.ru/otechnik/Vasilij_Zenkovskij/ preodolenie-platonizma-i-problema-sofijnoj-tvari/.

Kanke, V. A. Philosophy of Economic Science. Moscow: INFRA-M, 2007.

Mochernyi, S. V. Economic theory. Kyiv: Acad., 1999. 